\title{
Review on Effect of Shade Tree on Microclimate, Growth and Physiology of Coffee Arabica: In case of Ethiopia
}

\author{
Abebe Assefa ${ }^{1,2 *}$, Amisalu Gobena ${ }^{2}$ \\ ${ }^{1}$ Wochamo University College of Agricultural Science, Hossana, Ethiopia \\ ${ }^{2}$ Hawassa university, College of Agriculture, School of Plant and Horticultural Sciences, P.O.B. box 05 \\ *Corresponding Authors: Abebe Assefa, Wochamo University College of Agricultural Science, Hossana, \\ Ethiopia. Hawassa university, College of Agriculture, School of Plant and Horticultural Sciences,
}

\begin{abstract}
The seminar work conducted to review the effect of shade tree on microclimate, growth and physiology of coffee plants. To achieve this reviewed, microclimate, growth, and physiology of coffee plants growing under shade trees were compared with those of coffee plants growing under direct sun light. Different physiological, growth parameters, and microclimate environmental effect reviewed. Shade trees protected coffee plants against adverse environmental stresses such as high soil temperatures and low relative humidity. The light intensity in coffee declines under shade and that this depends on the shade tree species. The major effects of shade trees on the microclimate experienced by coffee plants can be summarized as a reduction in transmitted light and an improvement in microclimatic conditions through a reduction of air and coffee leaf temperature extremes. The higher growth in the shade plants from internodes elongation that was induced by low irradiance. The shade increased the number of node. The number of flowers branch between un shade and shade is affected by location of canopy. The fruit fall under shade was less than that of coffee grown in full sun. Coffee performs best when grown under suitable shade tree species with properly designed cropping system however, shade also triggered differences in physiological behavior of the coffee plants, such as improved photosynthesis and increased leaf area index, resulting in better performance than possible in direct sun light. Consequently, coffee plants grown under shade trees produced larger and heavier fruits with better bean quality than those grown in direct sun light. Moreover, shaded plants had greater biochemical and physiological potential for high dry matter production which would help them to maintain high coffee yields in the long term. If growing coffee under shade trees would allow other sources of income such as fruits, fuel wood and timber to be produced, it could be socially more acceptable, economically more viable and environmentally more sustainable. In this reviewed of literature I can recommended that of growing coffee in the shade had better performance and suggest that the future reviewed should be directed toward deterring the development of fungal diseases and increase of coffee yields under shaded conditions
\end{abstract}

Keywords: Coffee, Growth, microclimate, physiology, Shade

\section{INTRODUCTION}

\subsection{Background and Justification}

The word "coffee" comes from the name of a region in Ethiopia where coffee was first discovered 'Kaffa'. The name 'Kaffa' is inherited from the hieroglyphic nouns 'KA' and 'AfA'. 'KA' is the name of God; 'AFA' is then ame of earth and all plants that grow on earth. So the meaning of Koffee (Coffee) from its birth-place bells on as the land or plant of God. In addition to this, as a result of the genetic diversity of Ethiopian coffee, botanists and scientists agree that Ethiopia is the centre for the origin, diversification and dissemination of coffee plant (Bayetta, 2001). According to (Tadse, 2015), there are four types of coffee production systems in Ethiopia: forest coffee (10\%), semi forest coffee (35\%), garden coffee $(50 \%)$ and plantation coffee (5\%). Climatic factors, type of soil, mulching, farm management method, crop production methods, etc. are among the prominent factors that affect the growth and development of plants including coffee. Amongst the various factors for having a good yield of coffee is growing of shade trees with the coffee plant which has a great contribution on both the life span of the coffee trees and its yield (Senbeta 2006)

In many parts of the world, small scale coffee growers' uses multi-purpose trees (e.g. forage trees, fruit, nut trees, etc.) as shade, shelterbelt and windbreaks, for beautifying residential areas, and serve 

Ethiopia

as shelter for coffee plants from excessive sun and high temperatures. However, the management of maintaining optimal shade levels (around 40-50\%) and dealing with the pruning waste of the plants can also become a lot of work (ICO 2015). Traditionally, all coffee plants were shade grown and most varieties are naturally into learn to direct sunlight, and prefer a canopy of sun-filtering shade trees. The trees not only protect coffee from direct sun light, they also mulch the soil with their fallen leaves which helps to protect the soil from excessive temperature and retain soil moisture there of reducing evaporation (Njoroge and Kimemia, 1993; Vaast et al., 2006; Bote and Struik, 2011) . Coffee plantations managed in this traditional manner, as they mimic forests, will also provide a lively habitat which is able to harbor wildlife and different bird species. The birds in turn help to facilitate pollination and serve as a biological insect control for their unceasing foraging. It is therefore from this integrated farming system that the best quality coffee beans are produced (Tadse Woldemaria, 2015). However, as a result of the increased demand for coffee, a higher way of productivity, that is growing coffee plant in the open sun, was developed for coffee farming. This approach is followed by the continual application of chemical fertilizers and pesticides to keep up with the plants' faster growth rate and to make up for the loss of nutrients (because of severe soil erosion and removal of nitrogen-fixing trees from the surface).

The increased shift from shade grown to open sun coffee crop production systems has affected the quality of coffee available to most consumers. Amidst of the ecological benefits of forest trees for the sustainable and organic production of coffee as well as the benefits in conserving and use of coffee genetic resources, the forest resources are being cleared rapidly from the earth's surface at an alarming rate as a result of deforestation. landuse and land cover change. In Ethiopia, deforestation is estimated at 10,000 ha/year in the southwestern coffee growing regions (Molla mekonen, 2015). As a result of this the fauna and flora genetic resources of the country are being threatened posing a problem to the sustained development of the country.

In its center of origin and genetic diversity in Ethiopia, Coffea arabica grows wild in the Montana rainforests of southwestern as an under-story shrub in the deeply shaded forest canopy cover (Coste, 1992). Although, the crop is said to be a shade loving plant with greater quantum utilization efficiency for photosynthesis, excessive shading by upper two to three canopy strata of various tree species under forest environment would decrease growth and productivity of coffee trees because the plant spent much of their photosynthetic activities for maintenance purpose (Tesfaye et al., 2002).Heavy shading due to light penetration by the upper canopy strata can result in increased competition for light for photosynthesis. Subsequently, undesirable growth of single stemmed coffee trees with thin leaves and reduced reproductive efficiency are evident. Again, dark respiration can result in death of heavily shaded productive middle and bottom primary branches and thus productivity of the coffee tree considerably decreased (Tesfaye et al., 2002). On the other hand, in full sun conditions there will be inadequate reaction centers to accommodate the light energy and convert into biochemical energy and the coffee plant photo respires excessively and eventually most of the stored carbohydrates get depleted, which ultimate problem of shoot and root die-backs. Besides,excessive evapo transpiration and sever water stress, death of actively growing shoot parts, suchas branch tips, seasonal crinkling of leaves, frost damages "hot and cold disorder" and subsequent yield reduction are common problems in unshaded coffee stands (Cambrony,1992). The findings of Kumar (1979) indicated that coffee is a C3 or an intermediate between $\mathrm{C} 3$ and $\mathrm{C} 4$, flourishing best under moderate shade regimes. In line with this, Yacob et al. (1996) also demonstrated that coffee shade trees can create more favorable environments than full sun exposed conditions. Hence, Coffea arabica is a shade-adapted plant (Coste, 1992; Wintgens, 2004), but thrives best in moderate shading (Yacob et al.,1996). Despite this, the forest habitat of Coffea arabica gene pools is being disturbed largely due to deforestation practice in parallel with the increasing population pressure. Moreover, the indigenous shade trees are being drying because of age and other biotic stresses. Hence, investigation on the establishment of shade tree arboreta to simulate the original forest habitat of Coffea arabica is crucial for sustainable coffee production. Despite its decisive role in the national economy, coffee has remained small-holders crop in Ethiopia and thus predominantly produced under heterogeneous shade conditions. Taye and Tesfaye (2002) reported that this traditional farmers' production system can maintain environmentally friendly environments while producing high quality and fully organic coffees in the country. 
Agro forestry systems usually include a high density and diversity of shade trees. Such systems often have a large diversity of fauna and flora and provide local and regional ecosystem services. Shade trees are, however, being removed to increase crop production in many tropical regions. There is little knowledge on the effect of shade trees on crop production in the context of trade-offs with other management practices. Growing coffee under shade trees is one of the fundamental principles in traditional organic coffee growing systems (Beer et al., 1998). Shade trees reduce excessive light, mulch the soil with their litter, create hostile conditions for pests and diseases, and harbor a variety of predatory animals (Beer et al., 1998). Arabica coffee is a self-pollinated plant initiating heavy flowers that rapidly develop to fruits (Yunianto, 1986). During this period there is increasing carbohydrate absorption from both leaves and wood for flowers initiation and rapid fruits expansion. As a result roots are damaged, leaves are abscised and branches start dying from the tip and go back to the petiole. But, shade trees assist in maintaining coffee yields in the long term by reducing periodic overbearing and subsequent die-back of coffee branches. In addition, shading delays the maturation of coffee berries resulting in a better bean filling and larger bean size resulting in better coffee quality (Muschler, 2001).In Ethiopia, coffee was cultivated in this traditional way following the principles that (Lammerts van Bueren and Struik, 2004) called 'the concept of naturalness'. Soils were amended by applying compost, farm yard manure and green manure, while no chemical fertilizers, herbicides or fungicides were used. However, as demands for coffee production expanded, many coffee growers abandoned their traditional coffee growing system and started to grow coffee without shade trees. This new coffee production system was accompanied with intensive use of chemical fertilizers, insecticides, herbicides and fungicides resulting in blended and inferior coffee quality. Coffee plants in direct sunlight also showed a higher incidence of premature death (Steiman, 2003). In addition, the genetic resources of Coffea arabica and its associated biodiversity are disappearing at an alarming rate and environmental degradation, including soil erosion and extreme river discharges, is becoming severe (Gole et al., 2002; Osman, 2001). People in Ethiopia became unable to nourish their families and frequently became dependent on food aid. However, there is a growing worldwide movement to support and enhance organic coffee production systems under shade trees (Mark, 2005). This requires review of literature into the effects of shade on growth, production and physiology of coffee. The objective this review of literature, therefore, conducted with the main objective to evaluate the effect of shade tree on microclimate, growth and physiological response of known Coffea Arabica

\section{LITREATURE REVIEW}

\subsection{Effect of Shade Tree on Microclimate Change}

\subsubsection{Soil Temperature}

As Adugan and Pauol, 2011 studied Soil temperature and light intensity of shaded coffee plants were significantly lower than those of coffee plants grown in direct sun light, whereas the relative humidity of the air of the shaded plants was significantly higher than of plants grown in full sun light.

Soil temperature plays a critical role in the survival of many organisms, but it varies in response to exchange processes that take place through the surface of the soil. The reduction in soil temperature, observed under shade, was mainly caused by the ability of shaded soil to stabilize the local thermal balances and also to reduce the heat flux caused by the accumulated plant based biomass (Morais et al., 2006). Siebert (2002) also reported that shading reduces and stabilizes the soil temperature by reducing the radiant flux reaching the soil and modifying the temperature amplitude at the soil surface. The reduced air temperature registered for coffee grown under shade was in agreement with the result obtained by (Campanha et al., 2005). As they concluded the reduced air temperature was mainly due to the reduced direct incidence of solar radiation on the coffee canopy. Shading buffers the extreme temperature variations and provides a microclimate which attenuates extreme temperatures of air and soil and preserves surface soil humidity.

This finding was also agree with Lenka et.al, 2010 the average monthly soil temperature lower at shaded area than the non-shaded area. The non shaded area had higher soil temperature during the day and also during the night. Maximum ambient midday soil tempreture at lower depth were lower in the shaded area. Visible symptoms of damage of coffee can be caused by overheating (Willey, 1975). Although they found that the area without the protection of shade trees would get warmer, the differences in air temperatures in shaded and non-shaded areas were small (Morais et al. 2006) 


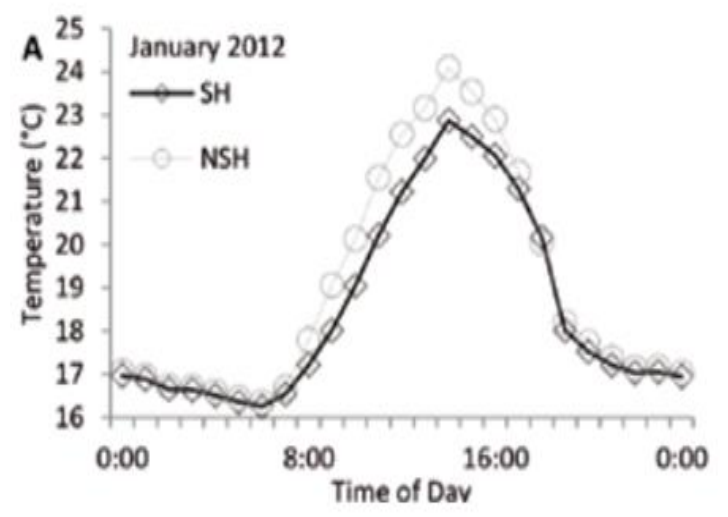

Source: - Mendel University in Bmo Department of Forest Botany. Available on line www.Forestry Joumal

Fig1. Shade effect on Soil temperature

\subsubsection{Light Intensity}

Light intensity of shade coffee plants were significantly lower than those of coffee plant grown in direct sunlight (Adugna and pauol, 2011). The reduction in soil temperature, observed under shade, was mainly caused by the ability of shaded soil to stabilize the local thermal balances and also to reduce the heat flux caused by the accumulated plant based biomass (Morais et al., 2006). Siebert (2002) also reported that shading reduces and stabilizes the soil temperature by reducing the radiant flux reaching the soil and modifying the temperature amplitude at the soil surface. The result obtained by (Campanha et al., 2005) indicated that, the reduced air temperature was mainly due to the reduced direct incidence of solar radiation on the coffee canopy.

According to (Jean M, and Pablos S, 2009), the canopy of I. densiflora trees had a strong influence on the microclimate experienced by coffee plants growing underneath, primarily through a reduction in light availability. Furthermore, the transmitted light was probably partially depleted in red wavelengths affecting the specific leaf area and architecture of the under-story plants as documented by (Staver et al. 2001). In shade tree coffee agro forestry system, coffee canopy light availability varied between 50 and $25 \%$ of the open radiation in the dry season and the wet season, respectively. These reductions are in the commonly observed range for coffee (40-70\%) according to many studies (Beer et al. 1998; Muschler and Bonnemann 1997; Vaast et al. 2005a). The low radiation values during the wet season are explained by the high canopy development of associated shade trees. In the central region of Costa Rica, farmers commonly pruned shade trees to reduce shade level for coffee. These low radiation levels are common and acceptable because coffee photosynthetic rates are at their maximum at intermediate radiation levels (PFD of 600-900 lmol m-2 s-1) in many coffee growing conditions (Vaast et al. 2005c; Franck et al. 2006). Indeed, coffee presents the characteristics of a shade adapted plant with a low light compensation point (15-20 lmol m-2 s-1), low values of light saturation (500 and $900 \mathrm{lmol} \mathrm{m-2} \mathrm{s-1} \mathrm{for} \mathrm{shade} \mathrm{and} \mathrm{sun} \mathrm{leaves,} \mathrm{respectively)} \mathrm{and} \mathrm{photo-inhibition} \mathrm{at}$ high radiation values, especially under water or nitrogen limiting conditions (Kumar and Tieszen 1980; Cannel 1985; da Matta and Maestri 1997; Franck 2005). This reduction in light and the variability between trees occurs because the transmittance of light is dependent on the structure and thickness of branches and leaves of the shade trees and density and width of the crown (Suryanto et.al. 2005). The small canopy diameter of Durian produced the least shade area and therefore allowed more light to be transmitted than other shade tree species. The small canopy in durian was partly the result of grower's harvesting Durian fruits resulting in fewer branches, low crown density and shade area and intensity (Suryanto et,al. 2005).

The observed decline in light intensity from the top to the bottom of the coffee canopy was a result of the combined effect of the shade trees and the coffee bush strata. A decrease in light intensity has been shown to be simultaneous with increasing thickness of the tree canopy (Suryanto et.al. 2005) and this is what occurred for the different levels (top, middle and bottom) within the coffee bushes. 


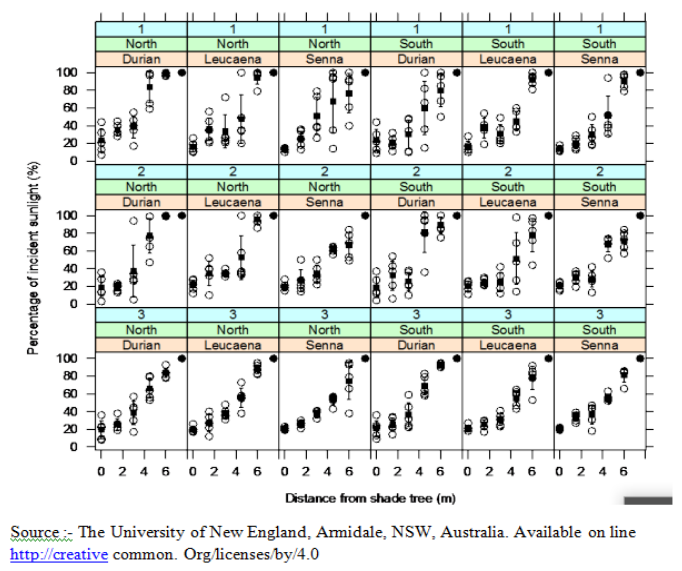

Fig2. Percentage of incident sunlight measured under the canopy of coffee bushes grown under Durian, Leucaena or Senna shade trees

\subsubsection{Relative Humidity}

As Gleison et al. 2016 studied the air humidity was higher at the shade area than non-shaded area. As in the case of air temperature for air humidity the daily flucation were smaller at the shade area (Lin, 2008). The higher humidity at the shaded area was in accordance with (Barradas and Fanjul, 1986), who explained it by higher output of water vapor produced by a much higher transpiration rate of canopy trees pumping water from lower soil layers. Additionally, shade of up to 55\% is beneficial for coffee leaf photosynthesis as it maintains greater coffee net photosynthesis relative to plants in full sun via a significant attenuation of stomata stress (Franck and Vaast, 2009). Higher humidity is favorable for coffee shrubs during the dry season, but it can be problematic during the wet season because of increased risk to the coffee shrubs from fungal diseases (Avellino et al., 2007). For example, coffee leaf rust (caused by Hemileia vastarix) generally develops during the rainy season (Avelino et al., 2006), but the lack of rain does not seem to be a significant limiting factor for developing this disease. Other sources of free water, such as dew, can facilitate the germination of spores during the absence of rain (Muller, 1975). Similarly, American leaf spot (caused by Mycena citricolor) develops in very damp conditions, and high humidity can cause epidemics of this disease (Wintgens, 2004). This finding also in lined with (Adugna and Pablous, 2011), the relative humidity of the air of the shaded plant was significantly higher than plants grown in full sun light.

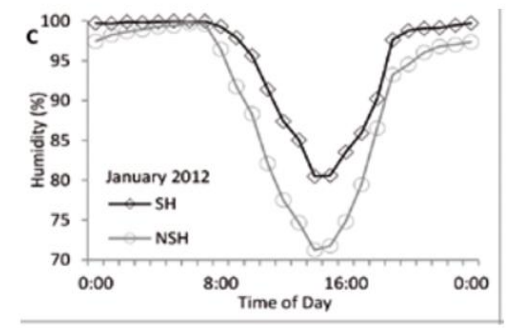

Source: - United Nations Development Programmer, Freetown, Sierra Leone Botany. Available on line www. http://dx.doi.org/jsd.v8ngp 66

Fig3. Shade effect on Relative humidity

\subsubsection{Air Temperature}

As the Gelision et.al 2016 showed Air temperature for the daily fluctuation was smaller at shade area the comparison of daily microclimate fluctuations for wet and dry months, the maximum temperature was $29.5^{\circ} \mathrm{C}$ at the shaded area and $31{ }^{\circ} \mathrm{C}$ at the non-shaded area.

The reduced air temperature registered for coffee grown under shade was in agreement with the result obtained by (Campanha et al., 2005). As (Adugna and pauolu , 20110 also agreed the reduced air temperature was mainly due to the reduced direct incidence of solar radiation on the coffee canopy. Shading buffers the extreme temperature variations and provides a microclimate which attenuates extreme temperatures of air and soil and preserves surface soil humidity. 
Review on Effect of Shade Tree on Microclimate, Growth and Physiology of Coffee Arabica: In case of Ethiopia

As pablos siles (2010) indicated measurements of leaf temperature in un-shaded coffee canopy and in coffee canopy grown under shade of I. densiflora showed a substantial buffering effect of shade on the thermal microenvironment. During the dry and wet seasons, coffee leaves without shade experienced temperatures higher than air temperature except for leaves located in the lower part of the canopy during Radiation. Temperature differences Stem basal area (m2ha-1) coffee leaves in the open and under shade were found to vary between $1^{\circ} \mathrm{c}$ and $7^{\circ} \mathrm{c}$ depending on time of the day, season and leaf position within the coffee canopy. These leaf temperature differences were similar to those reported in the literature for various coffee systems. In Mexico, (Barradas and Fanjul 1986) reported that the presence of Inga trees (205 trees ha-1) reduced the daily maximum temperature by $4-5{ }^{\circ} \mathrm{C}$ and increased the minimum temperatures by $1-2^{0} \mathrm{C}$. Similarly, $40-70 \%$ of shade provided by Erythrina poeppigiana or Terminalia ivorensis or Eucalyptus deglupta lowered leaf and soil temperatures in low elevation coffee zones to levels that are closer to optimum for coffee (Muschler and Bonnemann 1997; Vaast et al. 2007b). This reduction is of particular importance since the temperature range is between 18 and $24^{\circ} \mathrm{C}$ for an optimal photosynthesis of Arabica coffee (Cannel, 1985; Vaast et al., 2005 c; Franck et al., 2006) and with a detrimental effect of temperature above $25^{\circ} \mathrm{C}$ related to stomatal closure (Kumar and Tieszen 1980; ).Furthermore, additional positive temperature buffering effects of trees in AFS are also reported such as improved crop establishment, reduced soil evaporation, and enhanced activity of soil organisms (vanojen et.al,2008).

Table1. Average and statistical analysis of various environmental variable for shade coffee plant and coffee plant in direct sun light

\begin{tabular}{|c|c|c|c|}
\hline Variable & \multicolumn{2}{|c|}{ Treatment } & $\begin{array}{c}\text { Significance } \\
\text { two tailed }\end{array}$ \\
\hline Air temperature 0c & Shade plant & Plant in direct sun ligh & ns \\
\hline Soil temperature 0c & 25.5 & 26.7 & $0.00^{*}$ \\
\hline RH\% & 19.7 & 20.8 & $0.01^{*}$ \\
\hline Light intensity & 59.7 & 55.1 & $0.00^{* *}$ \\
\hline
\end{tabular}

Source. Adugna and Bote, 2011 available on line at.www.acadamic journas.org

\subsection{Effect Of Shade On Growth}

\subsubsection{Leaf Area}

Implementation of shade conditions significantly increased the coffee plant leaf area irrespective of the year season, when compared to unshaded conditions , as also found by others (Ricci et al., 2013). The differences among seasons and orientation side (northern or southern) may be related to both the sun inclination and the irradiance level. Arabica coffee seedlings growth under different radiation levels showed increased leaf area with decreased light (Tabagiba et al., 2010), whereas Conilon plants shaded by rubber trees showed the same pattern of higher leaf area (Partelli et al., 2014a). Valladares et al. (2006) found this effect in different plant species, in which the shaded leaves exhibited increased leaf areas per unit mass because of the lower intensity of received photon flux. According to these authors, the increased leaf area is a plant acclimation strategy under low light for harvesting the greatest possible light intensity. Overall, sun-exposed leaves are smaller because the mesophyll cell arrangement increases the contact surface with the air, allowing better latent heat loss and effective foliar cooling (Rubio-de-Casas et al., 2007).

Table2 Averages and statistical analysis of various plant variables for shaded coffee plant and coffee plants in direct sunlight

\begin{tabular}{|c|c|c|c|}
\hline Variable & \multicolumn{2}{|c|}{ Treatment } & \multirow{2}{*}{ Significance } \\
\hline & Shade plant & Plant in direct sun ligh & \\
\hline SLA $\left(\mathrm{cm}^{2} l g\right)$ & 116 & 98 & 0.04 \\
\hline $\mathrm{LAI}\left(\mathrm{M}^{2} \mathrm{~m}^{-2}\right)$ & 3.8 & 2.8 & 0.01 \\
\hline RGR $\left(\mathrm{Cm}^{-1} \mathrm{Cm}^{-1}\right)$ & 12.3 & 9.7 & Ns \\
\hline Leaf N content $\left(\mathrm{mgg}^{-1}\right)$ leaf dry matter & 288 & 219 & $0.03^{*}$ \\
\hline Leaf colour (value on greenness scale & -8.6 & -7.6 & $0.00^{* *}$ \\
\hline
\end{tabular}

Where $S A L=$ Specific leaf area, $L A I=$ Leaf area index, $R G R=$ Relative growth rate

Source: Adugna and Bote,2011 available on line at .www.acadamic journas.org 
Review on Effect of Shade Tree on Microclimate, Growth and Physiology of Coffee Arabica: In case of Ethiopia

\subsubsection{Internodes and Node}

The average internodes length of both plagiotropic/reproductive and orthotropic branches increased throughout the year in response to greater shading levels, as previously reported in coffee trees (Morais et al., 2003; Partelli et al., 2014a). The closer coffee plants to the Australian cedar on the southern side presented higher internodes lengths in reproductive branches throughout the year ( and from October onwards in orthotropic branches, likely related to the lower irradiance incidence. In fact, branch elongation is caused by shading to avoid low irradiance (Ricci et al., 2006) or in environments relatively rich in far-red light under low light conditions (Morgan and Smith, 1979). Accompanying the internodes length, also the accumulated branch growth showed variations during the year depending on the different shading levels, with increasingly differences starting immediately after the beginning of measurements. When evaluating the cumulative growth data in the last assessment for both orthotropic/reproductive and orthotropic branches, there were increases in these variables according to the increases in shading levels, but there was no significant difference between the non-shade grown coffee (Gelison et.al, 2016). The higher growth observed in the shaded plants is similar to the behavior presented in the branch etiolation, therefore, the shaded coffee showed the highest growth from internodes elongation that was induced by low irradiance incidence. On the other hand the study done by Gelison et.al, (2016) indicated, although shade seemed to increase the number of nodes per orthotropic branch, there were only non-significant changes when considering the entire year, suggesting similar potential for grain production under different shading levels. In fact, the number of nodes is a good indicator of the amount of productive bud gems available, and it is considered the largest productivity component (Bonomo et al., 2004). Similar numbers of rosettes between both sun-grown and shade-grown coffee were also previously reported by Ricci et al. (2013).Higher nodes values were observed in February in orthotropic coffee branches that were located $4.5 \mathrm{~m}$ from Australian cedar on the southern side.

\subsubsection{Plant Growth Parameters}

The studied done by Ricce et a. (2013) accordingly, highest value of plant height $93.33 \mathrm{~cm}$ was obtained under grass hat treatment followed by Sesbania with mean value of $77.32 \mathrm{~cm}$ per plant (Table 2). Similarly highest mean stem girth $3.1 \mathrm{cmwas}$ recordedunder grass hat (Gojo) treatment followed by Sesbania Sesban with mean value of $2.6 \mathrm{cmper}$ plant. This finding also supported by Bonomo et al., 2004 number of primary branch of coffee seedling was also considerably affected by shade tree species and highest 24 number of primary branch was obtained under grass hat pursued by Sesbaniaand pigeon pea with mean value of 23 and 20, respectively. The same treatment i.e., grasshat resulted in highest 14 number of node per plant perused by sesbania and pigeon pea with equal mean value of 13 (Table 1). This is due to variation in level of competition among the treatments. For instance grass hat has no competition effect on soil nutrients and soil moisture unlike the rest of the treatment. On the other hand less competition effect of sesbania might be due to wider spacing $(4 \mathrm{~m} \mathrm{x}$ $4 \mathrm{~m}$ ) used unlike the remaining temporary shade treatments

Table3. Effect of temporary shade tree species on non-distractive growth parameters of coffee seedling

\begin{tabular}{|c|c|c|c|c|}
\hline Treatment & PH $(\mathrm{cm})$ & Girth $(\mathrm{CM})$ & NPB & No of node \\
\hline Pigeon pea & $70.12 \mathrm{~b}$ & $2.3 \mathrm{bc}$ & $20 \mathrm{bac}$ & $14 \mathrm{ba}$ \\
\hline Sesbania & $77.32 \mathrm{ba}$ & $26 \mathrm{ba}$ & $23 \mathrm{ba}$ & $14 \mathrm{ba}$ \\
\hline Gras hate & $93.33 \mathrm{a}$ & $31 \mathrm{a}$ & $24 \mathrm{a}$ & $13 \mathrm{~b}$ \\
\hline Tephrosia & $60.91 \mathrm{~b}$ & $20 \mathrm{c}$ & $17 \mathrm{c}$ & $13 \mathrm{~b}$ \\
\hline Tephrosia & $68.68 \mathrm{~b}$ & $23 \mathrm{bc}$ & $19 \mathrm{c}$ & $13 \mathrm{~b}$ \\
\hline Castor bean & $65.04 \mathrm{~b}$ & $22 \mathrm{bc}$ & $19 \mathrm{c}$ & $8 \mathrm{c}$ \\
\hline Open & $74 \mathrm{ba}$ & $11 \mathrm{bc}$ & $8 \mathrm{bc}$ & 6.33 \\
\hline CV\% & 14.75 & 15.51 & 13.93 & 1.59 \\
\hline LSD $(0.05)$ & 19.48 & 4.01 & 5.41 & \\
\hline
\end{tabular}

Where $\mathrm{PH}=$ Plant Height $N P B=$ number of primary growth

Source. Source:-Addis et al (2015),journal of biology and Agriculture available on line WWW.iiste.org

Table4. Effect of temporary shade tree species on non-distractive growth parameters of coffee seedling

\begin{tabular}{|c|c|c|c|}
\hline Treatment & FPBL(cm) & HEPB (CM) & NLP \\
\hline Pigeon pea & $37 \mathrm{ab}$ & $21 \mathrm{ab}$ & $149 \mathrm{ab}$ \\
\hline Sesbania & $39 \mathrm{ab}$ & $22 \mathrm{ab}$ & $163 \mathrm{ab}$ \\
\hline Gras hate & $45 \mathrm{a}$ & $24 \mathrm{a}$ & $221 \mathrm{a}$ \\
\hline
\end{tabular}


Review on Effect of Shade Tree on Microclimate, Growth and Physiology of Coffee Arabica: In case of Ethiopia

\begin{tabular}{|c|c|c|c|}
\hline Tephrosia & $33 \mathrm{~b}$ & $20 \mathrm{~b}$ & $113 \mathrm{~b}$ \\
\hline Castor bean & 35 & $23 \mathrm{ab}$ & $102 \mathrm{~b}$ \\
\hline Open & 18 & $15 \mathrm{ab}$ & $56 \mathrm{ab}$ \\
\hline CV\% & 14.48 & 8.01 & 32.01 \\
\hline LSD (0.05) & 9.35 & 3.21 & 81.8 \\
\hline
\end{tabular}

Where FPBL=first primary branch length $H F P B=$ height up to first primary growth $\quad$ NLP=Number of leaf per plant

Source. Addis et al (2015),Journal of biology and Agriculture available on line www.iiste.org

\subsubsection{Flowering}

According to Chris et.al, (2015) flowering, there were no significant differences in the average number of flowers per branch per bush between shaded and unshaded coffee. This finding contrasts with previous work that found that shaded coffee produced fewer flowers as a result of fewer flower buds forming per branch, which related the reduction in light intensity (Baggio AJ et.al, 1997 and Montoyo L, A et.al 1961). This finding also agreed with Lin, (2008) who found that coffee grown under shade had more flowers per bush and flowers per node than coffee grown in full sun. As Tiem H,(1999) and Nam T,H (1999) indicated for the lack of difference between flowering at the open and shaded sites, is that upright growth was prevented due to height control through pruning and lateral branches or secondary growth were regularly pruned. This meant that all bushes were evenly spaced and sufficiently far apart to allow light and air to penetrate the foliage (Haarer, 1962). Daimata et,al (2008) is also found intensive coffee cultivation in the sites can also could contribute to successful flowering, resulting in insignificant different in flowers. With respect to vertical position in the coffee canopy, both shaded and unshaded coffee followed the same trend, whereby the number of flowers per branch per bush was similar for the top and middle of the canopy, but these were significantly higher than for the bottom. This result is similar to (Lin ,2008), who reported that self-shading caused significant light limitations and was highly likely to reduce flower bud initiation; the lowest branches and innermost branch nodes produced significantly fewer flowers than the outermost nodes and high and medium height branches (Huxey,1967). A decrease in light intensity was also shown to inhibited flower bud initiation by (Cannell, 1975). The study confirmed by Chris et.al, (2015) the light intensity at $30-90 \mathrm{~cm}$ aboveground bushes was about $400 \mu \mathrm{mm}-2 \cdot \mathrm{s}-1$, which is slightly lower than the saturation light intensity for coffee production. According to study done by Dalo (2003) and core (2015), the lower branch position (inside canopy and close to ground) grows slowly and poorly as a result of light and nutrient competition, it forms fewer fruit nodes and young branches, which results in lower yield compared to positions above.

\section{EFFECT OF Shade ON PHYSIOLOGY}

\subsection{Photosynthetic Rate (A)}

High rates of photosynthesis mean, according to Gulmon and Chu (1981), that there is high biochemical and physiological potential for a high carbon fixation capacity. To increase their carbon fixing potential, shaded plants undertake certain modifications such as developing thinner and larger leaves (Friend, 1984) with more thylakoids per granum and more grana per chloroplast (Fahl et al., 1994). These modifications allow them to efficiently capture and utilize the available light energy in order to increase their dry matter production. Plants having higher SLA exhibit higher productivity (Li et al., 2005) and have higher potential relative growth rate than those having lower SLA (Poorter and Werf, 1998). Robakowski et al. (2003) indicated that SLA decreases as light intensity increases. As Adugna and pablos, 2011 studied lower SLA was obtained from coffee plants grown in an open sun condition which is in consistence with the findings of these authors. For shaded coffee plants, the increased SLA and the development of a darker green color were mainly attributed to the higher nitrogen content found in their leaves. It is likely that the increased SLA and the development of dark green leaf color under shaded coffee plants partly contributed for the higher rate of photosynthesis observed under this condition. Photosynthetic rate of sun grown coffee plants, on the other hand, was limited by stomata closure, high leaf temperature and low internal carbon dioxide concentration. Since many of the physiological processes of plants are temperature dependent, under high temperature crops have great difficulty in maintaining photosynthetic activities and growth (Sethar et al., 2002). Coffee is exceptionally sensitive to fluctuations in leaf temperature, especially temperatures above $25^{\circ} \mathrm{C}$. 
Review on Effect of Shade Tree on Microclimate, Growth and Physiology of Coffee Arabica: In case of Ethiopia

Table5. Physiological parameters shaded coffee plant

\begin{tabular}{|c|c|c|c|c|}
\hline \multirow[t]{3}{*}{ Variable } & \multicolumn{2}{|c|}{ Treatment } & \multirow{3}{*}{$\begin{array}{l}\text { Significance } \\
\text { tailed }\end{array}$} & \multirow[t]{3}{*}{ two } \\
\hline & Shade plant & Plant in direct sun & & \\
\hline & & light & & \\
\hline $\mathrm{A}\left(\mathrm{umol} \mathrm{co} 2 \mathrm{~m}^{-2} \mathrm{~S}^{-1}\right)$ & -3.5 & 2.45 & $0.03 *$ & \\
\hline $\mathrm{Fv} / \mathrm{Fm}(-1)$ & 0.71 & 0.61 & $0.01 *$ & \\
\hline $\begin{array}{l}\text { Stomatal conductance } \\
\left(\mathrm{mmolm}^{-2} \mathrm{~S}^{-1}\right)\end{array}$ & 100 & 60 & ns & \\
\hline $\begin{array}{l}\text { Transpiration Rate (umol } \\
\text { photons } \mathrm{m}^{-2} \mathrm{~S}^{-1} \text { ) }\end{array}$ & 1010 & 1140 & ns & \\
\hline PAR(umol photons $\mathrm{m}^{-2} \mathrm{~S}^{-1}$ ) & 320 & 2260 & $0.00 * *$ & \\
\hline Leaf temperature $\left({ }^{0} \mathrm{c}\right)$ & 24.2 & 28.1 & $0.00 * *$ & \\
\hline
\end{tabular}

Source: - Adugna and Bote, 2011 available on line at .www.acadamic journas.org)

The ecological behavior of plants and their health status can be judged by considering certain parameters. For example, SLA reflect the growing conditions of the plants (Garnier et al., 2001), where as LAI and the Fv/Fm ratio are indicators of the health status of a given crop plant (Kitao et al., 2000; Malone et al., 2002). Higher LAI observed for coffee plants growing under shade indicated that these plants have higher potential for $\mathrm{CO} 2$ assimilation and dry matter production than unshaded plants (McNaughton and Jarvis, 1983). Higher Fv/Fm ratio observed for shaded coffee plants illustrated the fact that these plants are less stressed by high light intensity than those grown in direct sun light. Sethar et al. (2002) supported this idea indicating Fv/Fm ratio decreases significantly when plants are exposed to heat stress. For plants grown under higher irradiance, the reduced value of $\mathrm{Fv} / \mathrm{Fm}$ ratio is an indication of the damage of a proportion of reaction centres, a phenomenon called photo-inhibition. Once a proportion of a PSII reaction centre is damaged, light energy utilization capacity of this centre decreases resulting in a reduced quantum yield of net photosynthesis (Rintamaki et al., 1995; Maxwell and Johnson, 2000). Light, as energy source for photosynthesis, is an essential prerequisite for plant life. Excess light, however, can inhibit photosynthesis and lead to photo-oxidative destruction of the photosynthetic apparatus, thereby decreasing the photosynthetic rate of the plant growing in direct sun light besides affecting its life span (Li et al., 2010). According to Fahl et al. (1994) and Ramalho et al. (2000), higher values of Fv/Fm obtained from shaded leaves can also be linked with higher leaf nitrogen content. Under stressed conditions the availability of more leaf nitrogen triggers photo protective mechanisms against photo-oxidation by its ability in promoting the activation and backing up of the protective mechanisms (Fahl et al., 1994). Leaf nitrogen was also found to have a strong and positive correlation with carbon assimilation rates allowing shaded leaves to have better photosynthetic performance and greater vegetative growth rate than sun leaves. Therefore, coffee plants found in direct sun light were grown under environmental conditions that are more likely to lead to plants stress responses, compared with the environmental conditions under which shaded plants are grown

\subsection{Stomata Conductance}

As Adugna (2011) studied for the coffee plants grown in direct sun light, increased air temperature above this level resulted in subsequent lowering of stomatal conductance, which in turn imposed a large limitation on the rate of $\mathrm{CO} 2$ assimilation. Kasai (2008) has also found comparable results: stomatal conductance and photosynthetic rate were found significantly lowered by growing soybean plant under continuous light. High temperatures, according to Farquhar and Sharkey (1982), reduce the electron transport capacity and increase the rates of $\mathrm{CO} 2$ evolution from photorespiration and other sources causing the photosynthetic rate to become lower. As stomata are highly responsive to the factors that influence the rate of transpiration, their movements can also be affected by leaf-to-air 
vapour pressure difference (Kim et al., 2004). Under shade, however, reduced air temperature and light intensity increased the percentage relative humidity in the air around coffee plants and subsequently reduced the vapour pressure deficit (VPD) between the interior of the leaf and the atmosphere. This reduced VPD decreased rate of transpiration of the leaf resulting in increased leaf water potential. Under such small VPD, stomata aperture increases providing better chance for $\mathrm{CO} 2$ to be diffused into the leaf

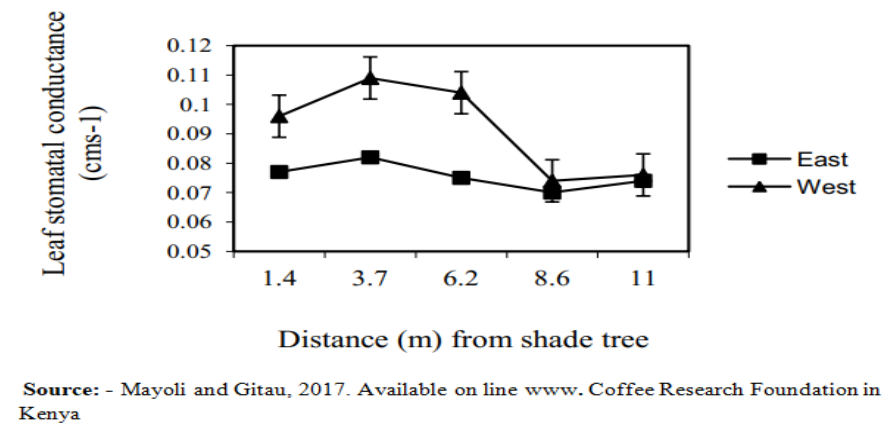

Fig4. Leaf stomata conductance (cms-1) of coffee plants planted at varying distances from shade trees

\subsection{Photo Synthetically Active Radiation (PAR)}

According studied done bay Adugna (2011) due to the interception of solar radiation by shade trees, the incident solar radiation, PAR, was greatly reduced for coffee grown under shade. But, plants under shade had a higher photosynthetic rate. Coffee in full sun recorded higher photosynthetically active radiation (PAR) reaching it than shaded coffee. This agrees with the findings by Baliza et al., (2012) who also observed a decrease in photosynthetically active photon flux density (PPFD) with increase of the shading level due to the effect of tree leaves filtering out the red light and transmitting the green. The PAR reaching coffee trees also increased with increasing distance from shade tree (reducing shade level).This paradox can be explained by the fact that plants under shade undertake certain morphological modifications and physiological adaptations, and their leaves are capable of absorbing more than $90 \%$ of the energy contained in the wavelengths between 400 and $700 \mathrm{~nm}$ (Lee, 1985). In addition, Bartlett and Remphrey (1998) indicated that there are no significant reductions in photosynthetic rate and growth of coffee plants grown under shade unless the level of shade exceeds $90 \%$. The darker green colour of coffee leaves developed in the shade was most likely associated with the larger amount of nitrogen accumulated in them (Titus and Pereira, 2005). Leaves having such dark green colour absorb more light, have chloroplasts with improved light capturing capability and are cheap units of photosynthetic area (energetically) as they capture lower light intensity and utilize them efficiently to increase their photosynthetic rate.

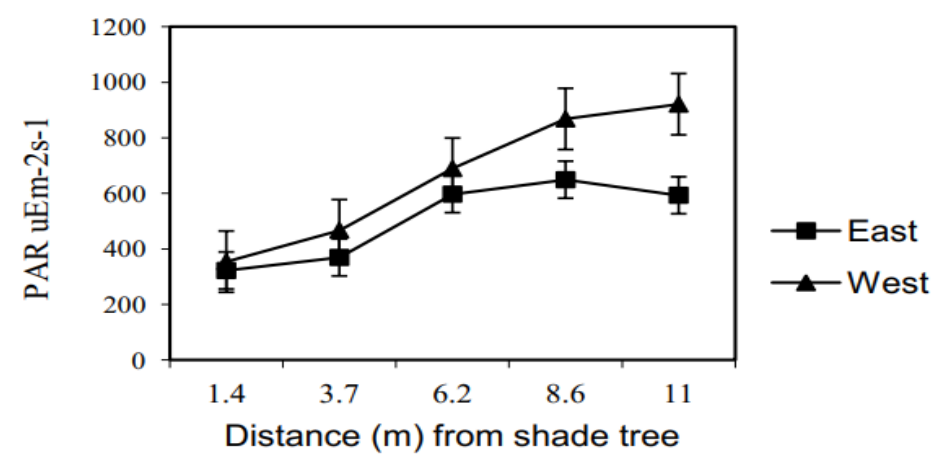

Source: - Mayoli and Gitau, 2017. Available on line www. Coffee Research Foundation in Kenya

Fig5. Photosynthetic active radiation (PAR; $\mu E m-2 s-1)$ of coffee planted at varying distances from shade trees

\subsection{Leaf Temperature}

The work done by Odeny (2016) leaf temperature was significantly affected by shade during the dry period but not during the rainy period. As he observed, leaf temperatures tended to be lowest in the 
morning, peaking at midday then decreasing thereafter. Very high leaf temperatures of up to $38^{\circ} \mathrm{C}$ were attained in full sun coffee at midday in the dry period. Leaf temperatures are generally higher than air temperatures since leaves are heated by absorbing solar radiation. Likewise, Chaves et al., (2008) recorded leaf temperatures of up to $35^{\circ} \mathrm{C}$ in sunlit leaves and Siles and Vaast (2002) recorded temperatures of above $25^{\circ} \mathrm{C}$. Shaded coffee tended to have lower leaf temperatures than un shaded coffee during the dry period, with the difference ranging from an average of $1.2^{\circ} \mathrm{C}$ to $1.93^{\circ} \mathrm{C}$. Jassogne et al. (2013) similarly observed that shade reduced temperatures in the coffee trees by up to $2^{\circ} \mathrm{C}$. Baliza et al., (2012) found that leaf temperatures for both dry and rainy season were highest under full sun but declined with increase in shading level. This finding also supported by Siles and Vaast(2002) who registered coffee leaf temperatures $2^{\circ} \mathrm{C}$ higher, in full sun during the dry season, than under Eucalyptus deglupta or Terminalia ivorensis shade.

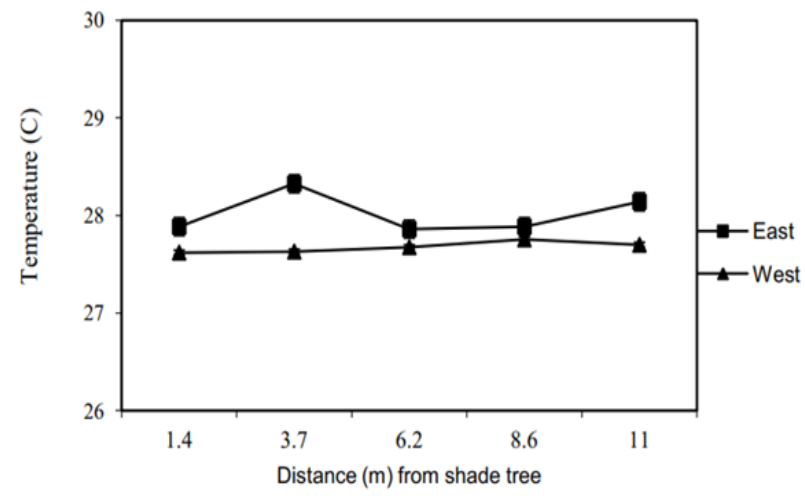

Kim et al., 2012. Available on line WWW. Afr. J. Hort. Sci. (June 2012) 6:35-42

Fig6. Influence of shade on leaf temperature (OC) of coffee plants planted at varying distances from shade trees

\subsection{Transpiration Rate}

Generally, shaded coffee had higher transpiration rate than coffee in full sun with the exception of the dry period Odeny, (2016). The findings are comparable to those reported by van Kanten and Vaast (2006) who showed that, while coffee transpired more per unit leaf area in full sun, the diurnal water intake per hectare was higher under shade. They further observed that the annual pooled water transpiration by coffee and associated shade trees ranged from 20 to $250 \%$ more than sole coffee grown in full sun. Results of this study show that shade had a significant effect on transpiration rate during the dry and rainy seasons. The low transpiration could be attributed to the fairly high leaf temperatures that were registered during this study. As reported by Gates (1968), leaf temperature determines the vapour pressure deficit (VPD) within the leaf and is therefore the prime mover of transpiration. The results were supported by Hernandez et al., (1989) and Mayoli and Gitau (2012) who observed a strong and direct reaction of stomata to VPD. Van Kanten and Vaast (2006) found that coffee transpiration was restricted at higher VPD, recorded during the dry period, due to stomata closure

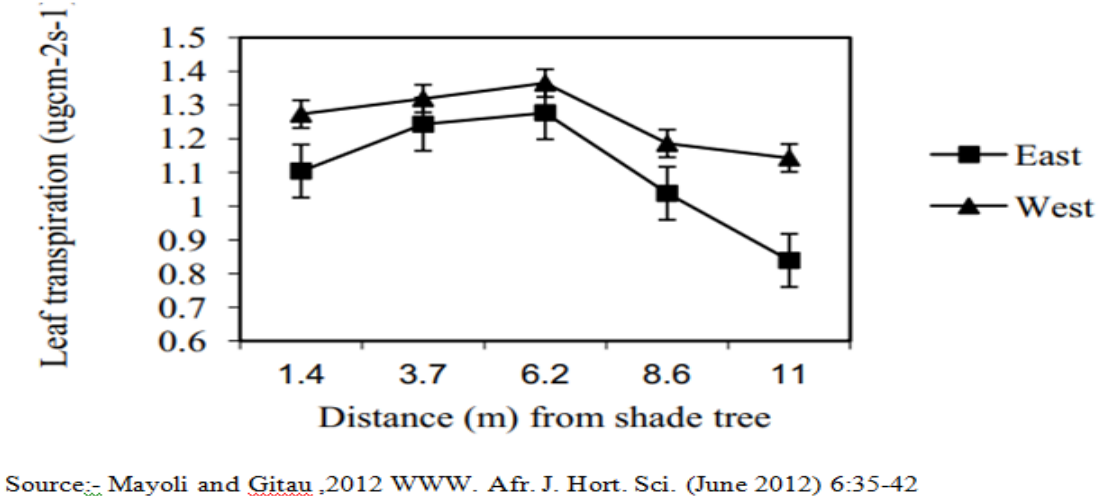

Fig7. Leaf transpiration ( $\mu \mathrm{gcm}-2 \mathrm{~s}-1)$ of coffee plants planted at varying distances from shade 


\section{SUMMERY AND CONCLUSION}

We detected both positive and negative effects of shaded trees on microclimate conditions of coffee plantation. Positive effects included the reduction of air as well as soil temperature changes. One negative effect could be the increase in number days with lower soil water availability in the shaded area. The monthly maximum temperature was higher in the non-shaded area, but even there, it would not pose a serious problem for photosynthesis. Additionally, the shaded area showed higher air humidity than non-shaded area, which could be problematic if it promotes fungal diseases. However, the most important results were from soil measurements, which showed greater duration of severely dry conditions in the shaded area. Such lower soil water availability could pose problems for coffee production in drier climates.

The light intensity in coffee declines under shade and that this depends on the shade tree species. The closer to the shade tree, light intensity tended to be decreased. The light intensity decline in light intensity recorded from the top to the bottom of coffee canopy. The number of flowers branch between un shade and shade is affected by location of canopy. The fruit fall under shade was less than for coffee grown in full sun. Coffee performs best when grown under suitable shade tree species with properly designed cropping system. Leaf area is increased under shade trees, because of the lower intensity of received photon flux. The average internodes length increased in response to greater shading levels. The higher growth in the shade plants from internodes elongation that was induced by low irradiance. The shade increased the number of node and the higher yield obtained from coffee plant in direct sun light plantation because of high light intensity but the coffee trees has short life time because high evaportansiparation. The specific leaf area, leaf area index, relative growth rate higher under shade tree than that open sun coffee production system.

The physiological response of coffee trees photosynthic rate, photosythnic active radiation chlorophyll fluorescence, and stomata conductance higher in coffee production under shade tree, and also transpiration rate and leaf temperature is lower coffee production in open sun

\section{REFRENCES}

[1] Adugna and Pauol. (2011). Effect of shade on growth,production and quality of coffee Arabica.

[2] Avaliable on line Available online at http://www.academicjournals.org/JHF

[3] Avelino, J., Zelaya, H., Merlo, A., Pineda, A.,Ordoñez, M., Savary, S. (2006). The intensity ofa coffee rust epidemic is dependent on production situations. Ecol Model 197:431-447

[4] Avelino, J., Cabut, S., Barboza, B., Barquero, M., Alfaro, R., Esquivel, C., Durand, J.F., Cilas, C. (2007). Topography and crop management are key factors for the development of American leaf spot epidemics on coffee in Costa Rica. Phytopathology 97:1532-1542

[5] Barradas, V.L., Fanjul, L. (1986). Microclimatic characterization of shaded and open-grown coffee (Coffea arabica) plan tations in Mexico. Agric For Meteorol 38:101-112

[6] Bartlett, G.A., Remphrey, W.R. (1998). The effect of reduced quantities of photo synthetically active radiation on Fraxinus pennsylvanica growth and architecture. Can. J. Bot., 76: 1359-1365.

[7] Baliza, D.P., Cunha, R.L., Guimarães, R.J., Barbosa, J.P.R.A.D., Avila, F.W. Passos, A.M.A. (2012). Physiological characteristics and development of coffee plants under different shading levels

[8] Bayetta, B. (2001). Arabica coffee breeding for yield and resistance to coffee berry disease

[9] (Colletotricum kahawah sp.), Doctoral Thesis, Imperial College Wye University, London.

[10] Baggio, A., Caramori, P., Androcioli Filho, A., and Montoya, L. (1997). Productivity of Southern Brazilian Coffee Plantations Shaded by Different Stocking of Grevillea robusta, AgroforestrySystems.http://dx.doi.org/10.1023/A:1005814907546

[11] Beer, J., Muschler, R., Kass, D., Somarriba, E. (1998). Shade management in coffee and cacao plantations. Agroforestry Systems, 38: 139-164.

[12] Bote, A.D., and Struik, P.C. (2011). Effects of shade on growth, production and quality of

[13] coffee (Coffea arabica) in Ethiopia. Journal of Horticulture and Forestry 3 (11): 336-341.

[14] Cambrony, H.R.(1992).Coffee growing. CTA/The Macmillan Press LTD, New York,Tokyo.

[15] Campanha, M.M., Silva, R.H., Freitas, G.B., Martinez, H.E., Gracia, S.L., Fing, F.L. (2005). Growth and yield of coffee plants in agroforestry and monoculture systems in Minas Gerais, Brazil. Agroforestry Syst., 63(1): $75-82$. 
[16] Cannell, M.G.R. (1985). Physiology of the Coffee Crop. In: Clifford, M.N. and Willson, K.C., Eds., Coffee, Springer, Berlin, 108-134. http://dx.doi.org/10.1007/978-1-4615-6657

[17] Campanha M.(2005). Growth and Yield of Coffee Plants in Agroforestry and Monoculture Systems in Minas Gerais,Brazil. Agroforestry Systems, 63, 75-82. http://dx .doi. org/10.1 023/B:AGFO. 00000494 $35.225122 \mathrm{~d}$

[18] Cannell, M.R.G. (1975). Crop physiological aspects of coffee bean yield: a review. J Coffee Res 5:7-20

[19] Chaves, A.R.M,, Ten-Caten, A., Pinheiro, H.A., Ribeiro, A., and DaMatta, F.M. (2008). Seasonal changes in photoprotective mechanisms of leaves from shaded and unshaded field grown coffee (Coffea arabica L.) trees. Trees 22: 351- 361 .

[20] Chris, S. (2015). The Effects of Shade Tree Types on Light Variation and Robusta Coffee Production in Vetnam. Avaliable on line Published Online November 2015 in SciRes. http://www.scirp.org/journal/eng

[21] Coste, R. (1992). Coffee: The plant and the product. Macmillan, London.

[22] Da Matta, F.M., Maestri, M. (1997). Photo inhibition and recovery of photosynthesis in Coffea arabica and C. canephora. Photosynthetica 34(3):439-446

[23] DaMatta, F.M. (2008) .Eco physiology of Coffee Growth and Production. Brazilian Journal of Plant Physiology, 19, 485-510. http://dx.doi.org/10.1590/S1677 04202007000400014

[24] Dao, N.T. (2003). Coffea. In: Hieu, N.M., Ed., Industrial Crop Textbook. Industrial Plants Curriculum, Agricutural Publication, Ha Noi.

[25] Fahl, J.I., Carelli, M.C., Vega, J., Magalhaes, A.C. (1994). Nitrogen and irradiance levels affecting net photosynthesis and growth of young coffee plants (Coffea arabica L.). J. Hort. Sci., 69: 161-169.

[26] Farquhar, G.D., Sharkey, T.D. (1982). Stomata Conductance and Photosynthesis. Annu. Rev. Plant. Physiology, 33:317-345.

[27] Franck, N., Vaast, P. (2009). Limitation of coffee leaf photosynthesis by stomatal conductance and light availability under different shade levels. Trees. 23(4):761-769

[28] Franck, N. (2005). Effect de la charge en fruits et de l'ombrage sur l'assimilation carbone'e, la croissance et la production du cafe 'ier (Coffea arabica L.). The`se de Doctorat, ENSA, Montpellier, pp 175

[29] Franck, N.,Vaast, P., Ge'nard, M., Dauzat, J. (2006). Soluble sugars mediate sink feedback down regulation of leaf photosynthesis of Coffea arabica in the field. Tree Physiol 26:517-5

[30] Friend, D.C. (1984). Shade adaptation of photosynthesis in coffea arabica. J. Photosynthesis Res., 5(4): $325-334$.

[31] Jassogne, L., Läderach, P., and Van Asten, P. (2013). The impact of climate change on coffee in Uganda. Lessons from a case study in the Rwenzori Mountains. Oxfam Researchreport

[32] Gates, D.M. (1968). Transpiration and leaf temperature. Annual Review of Plant Biology 19:211 238

[33] Garnier, E., Shipley, B., Roumet, C., Laurent, G. (2001). A standardized protocol for the determination of specific leaf area and leaf dry matter content. Funct. Ecol., 15: 688-695.

[34] Gleison,G. (2016). Microclimate and development of coffee under different shading leveli .Avaliable om WWW.Austrian Journal of Agriculture

[35] Gole, T.W., Denich, M., Demel, T., Vlek, P.L.G. (2002). Human Impacts on Coffea Arabica Genetic Pools in Ethiopia and the Need for its In situ Conservation. In: Managing Plant Genetic Diversity, Rao, R., A. Brown and M. Jackson (Eds.). CAB International and IPGRI, pp: 237- 247.

[36] Gulmon, S.L.,Chu, C.C. (1981). The effects of light and nitrogen on photosynthesis, leaf characteristics, and dry matter allocation in the chaparral shrub, Diplacus aurantiacus. Oecologia, 49:207-212.

[37] Hernandez, A.D.P., Cock, J. H., and El-Sharkawy, M.A. (1989). The responses of leaf gas exchange and stomatal conductance to air humidity in shade-grown coffee, tea and cacao plants as compared with sunflower. Brazilian Journal of Plant Physiology 1(2): 155 - 161.

[38] Haarer, A.E. (1962). Modern Coffee Production. 2nd Edition, Modern Coffee Production, London

[39] Huxley, P.A. (1967). The Effects of Artificial Shading on Some Growth Characteristics of Arabica and Robusta Coffee Seedlings. I. The Effects of Shading on Dry Weight, Leaf Area and Derived Growth Data. Journal of Applied Ecology, 4, 291-308. http://dx.doi.org/10.2307/2401337

[40] Kasai, M. (2008). Effect of growing soybean plants under continuous light on leaf photosynthetic rate and other characteristics concerning biomass production. J. Agron., 7: 156-162.

[41] Kim, H., Gregory, D.G., Raymond, M.W., John, C.S. (2004). Stomata conductance of lettuce grown under or exposed to different light qualities. Ann. Bot., 94: $691-697$.

[42] Kitao, M. Lie, T.T., Koike, T., Tobita, H., Maruyama, Y. (2000). Susceptibility to photo inhibition of three deciduous broad leaf tree species with different successional traits raised under various light regimes. Plant Cell Environ, 23(1): $81-89$. 
Review on Effect of Shade Tree on Microclimate, Growth and Physiology of Coffee Arabica: In case of Ethiopia

[43] Kumar D.(1979).Some aspects of the physiology of Coffea arabica L.A review. Kenya Coffee 44(519): 9-47.

[44] Kumar, D., Tieszen, L. L . (1980). Photosynthesis in Coffea arabica. I Effects of light and temperature. Exp Agric 16:13-19

[45] ICO, (2015). Coffee Production Data. Www.ico.org. Accessed on August 8, 2015: International Coffee Organization.

[46] Lammerts van Bueren, E.T., Struik, P.C. (2004). The consequences of the concept of naturalness for organic plant breeding and propagation. NJAS-Wageningen J. Life Sci., 52(1): 85 - 95.

[47] Lee, D.W. (1985). Duplicating foliage shade for research on plant development. Hort. Sci., 20: 116 - 118.

[48] Lin, B.B. (2008). Microlimate Effects on Flowering Success in Coffee Agroforestry Systems. AmericanEurasian Journal of Agricultural \& Environmental Sciences, 3, 148-152.

[49] Li, H.,Yong, Y. Li, B.,Jing, R. Lu., C.Li, Z. (2010). Genetic analysis of tolerance to photo-oxidative stress induced by high light in winter wheat (Triticum aestivum L.) J. Genet. Genom., 37(6):399-412.

[50] Li, Y., Douglas, A.J. ,Yongzhong, S.U., Jianyuan, C.I.,Tonghui, Z. (2005). Specific leaf area and leaf dry matter content of plants growing in sand dunes. Bot. Bull. Acad. Sinica., 46: 127 - 134.

[51] Partelli, F.L., Araújo, A.V., Vieira, H.D. „Dias, J.R.M., Menezes, L.F.T., Ramalho, J.C. (2014a). Microclimate and development of 'Conilon' coffee intercropped with rubber trees. Pesqui Agropecu Bras. 49(11):872-881.

[52] Malone, S., Herbert, D.A., Holshouser, D.L.( 2002). Relationship between Leaf Area Index and yield in Double-crop and full-season soybean systems. J. Ecol. Entomol., 95(5): 945-951.

[53] Mark, J.( 2005). Shade grown coffee and bird-friendly coffee. http:// www. thenibble. com/REVIEWS /n utri/matter/organic-coffee 4 .asp

[54] Mayoli, R. N., and Gitau, K.M.( 2012). The effects of shade trees on the physiology of Arabica coffee. African Journal of Horticultural Science 6: $35-42$.

[55] Maxwell, K., Johnson, G.N. (2000). Chlorophyll fluorescence - a practical guide. J. Exp. Bot.51:659 668.

[56] McNaughton, K.G., Jarvis, P.G. (1983). Predicting effects of vegetation changes on transpiration and evaporation. In: Water Deficits and Plant Growth. Vol. 7, Kozlowski, TT (ed.), pp. 1-47 London Academic Press, New York.

[57] Molla, M. (2015). Effect of tree shade on coffee crop production.Avaliable on line Journal of Susstainable development

[58] Morais, H., Caramori, P., Ribeiro, A.M., Gomes, J.C., Koguishi, M.S. (2006). Microclimatic characterization and productivity of coffee plants grown under shade of pigeon pea in Southern Brazil. Pesq. Agropec. Bras. 41: 5. 763-770.

[59] Muschler, R.G. (2001). Shade improves coffee quality in a sub-optimal coffee-zone of Costa Rica. Agroforestry Syst., 51(2): $131-139$.

[60] Muschler, R.G., Bonnemann, A. (1997). Potentials and limitations of agroforestry for changing land-use in the tropics: experiences from Central America. For Ecol Manag 91:61-73

[61] Morais, H., Marur, C.J., Caramori, P.H., Ribeiro, A.M.A., Gomes, J.C.( 2003). Physiological characteristics and growth of coffee plants grown under shade of pigeon pea and unshaded. Pesqui Agropecu Bras. 38(10):1131-1137.

[62] Morgan, D.C., Smith, H. (1979). Systematic relationship between phytochrome-controlled development and species habitat for plants grown in simulated natural irradiation. Planta. 145(3):253-258

[63] Montoya, L.A., Sylvain, P.G., and Umana, R. (1961). Effect of Light Intensity and Nitrogen Fertilization upon Growth Differentiation Balance in Coffea arabica L. Coffee, 3, 97-104

[64] Njoroge, J..M., and Kimemia, J.K. (1993). Current observations and future trends in coffee intercropping studies in Kenya. Outlook in Agriculture 22: 43 - 48.

[65] Osman, M. (2001). Rainfall and its erosivity in Ethiopia with special consideration of the central highlands. -Bonner Bodenkundl. Abh., 37, 249 S. Bonn.

[66] Tadse, w. (2015). Ethiopian Coffee Production System, Environment and coffee forest form,

[67] Taye Kufa., and Tesfaye Shimber. (2002). Organic coffee production: hope for small-scale Addis Ababa ,Ethiopia farmer in Ethiopia. Proceedings of the 19th International Conference on Coffee. Science (ASIC), May 14th-18th, 2001, Trieste, Italy

[68] Tesfaye Shimber, ,Taye Kufa., and Alemseged Yilma. (2002). The effect of established shade trees on the growth and yield of arabica coffee in two planting patterns: Proceedings of the International Conference on Coffee Science (ASIC), May 14th-. 18th, 2001, Trieste, Italy. 
[69] Tiem, H.T. (1999). Coffee Physiology. In: Nhan, D.T., Tiem, H.T. and Sung, P.Q., Eds., Coffee Crop in Vietnam,Agriculture Publication, Ha Noi, 64-86.

[70] Tiem, H.T. (1999). Ecological Requirement of Coffee. In: Nhan, D.T., Tiem, H.T. and Sung, P.Q., Eds., Coffee Crop in Vietnam, Agriculture Publication, Ha Noi, 51-63.

[71] Titus, A., Pereria, G. (2005). Nitrogen Economy inside Coffee Plantations in Van Wijk MT Williams M, Laundre JA, Shaver GR (2003). Inter annual variability of plant phenology in tussock tundra: modeling interactions of plant productivity, plant phenology, snowmelt and soil thaw. Global Change Biol., 9:743758

[72] Poorter, H., Werf, V.A. (1998). Is inherent variation in RGR determined by LAR at low irradiance and by NAR at high irradiance? A review of herbaceous species. In: Lambers, H, Poorter, H, Van Vuuren, MMI (eds.). Inherent variation in plant growth. Physiological mechanisms and ecological consequences. Leiden, Netherlands, Backhuys Publishers. pp. 309-336.

[73] Ramalho, J.C., Pons, T.L., Groeneveld, H.W., Azinheira, H.G., Nunes, M.A. (2000). Photosynthetic acclimation of high light conditions in mature leaves of Coffea arabica L.: Role of xanthophylls, quenching mechanisms and nitrogen nutrition. Aust. J. Plant Physiol., 27(1): 43- 51.

[74] Rintamaki, E., Kettunen, R., Tyystjärvi, E. ,Aro, E.M. (1995). Light dependent phosphorylation of D1 reaction-centre protein of Photosystem II: Hypothesis for the functional role in vivo. Physiol. Plant. 93: $191-193$

[75] Ricci, M.S.F., Costa, J.R., Pinto, A.N., Santos, V.L.S. (2006). Organic cultivation of coffee cultivars grown under full sun and under shading. Pesqui Agropecu Bras. 41(4):569-575.538

[76] Ricci, M.S.F., Cocheto Junior, D.G., Almeida, F.F.D. (2013). Micro weather conditions, phenology and external morphology of Coffee trees in shaded and full sun systems. Coffee Sci. 8(3):379-388.

[77] Rubio-De-Casas, R., Pérez-Corona, E., Manrique, E.,Quintana, J.R., García-Verdugo, C., Balaguer, L. (2007). Field patterns of leaf plasticity in adults of the long-lived evergreen Quercus coccifera. Ann BotLondon. 100(2):325-334.

[78] Robakowski, P., Montpied, P., Dreyer, E. (2003). Plasticity of morphological and physiological traits in response to different levels of irradiance in seedling of silver fir (Abies alba Mill.) Trees, (Berl.). 7: 431-441.

[79] Sethar, M.A., Pahoja, V.M., Chachar, Q. (2002). Photosynthetic acclimation of cotton genotypes at higher temperatures. Asian J. Plant Sci. 1: 261-263.

[80] Siles, P.D.G., and Vaast, P. (2002). Comportamiento fisiológico del café asociado Eucalyptus deglupta, Terminalia ivorensis y sin sombre. Agroforestería en las Américas 9(35-6)

[81] Siebert, S.F. (2002). From shade- to sun-grown perennial crops in Sulawesi, Indonesia: Implications for biodiversity conservation and soil fertility. Kluwer Academic Publisher, the Netherlands. Biodivers. Conserv., 11(11): 1889 - 1902.

[82] Senbeta, W.F.( 2006). Biodiversity and ecology of afromontane rainforests with wild Coffea arabica L. populations in Ethiopia. Ecology and Development Series No. 38, Center for

[83] Development Research. University of Bonn. Staver, C. (2001). Designing Pest-Suppressive Multistrata Perennial Crop Systems: Shade

[84] Grown Coffee in Central America. Agroforestry Systems, 53, 151-170.http:// dx.doi.org /10.1023/ A: 1013 372403359

[85] Steiman, S. (2003). Shade vs. Sun Coffee: A review PMicrosoft internet explorer. www. Geocities .com/ RainForest/Canopy/1290/basics.htm (accessed 24 January 2006).

[86] Suryanto, P., Tohari, M.S., and Sabarnurdin. (2005). Dinamics of Resources Sharing System in Agroforestry: Based of Compilation Consideration Silviculture Strategy. Agriculture Science Journal, 2 , 165-178.

[87] Tabagiba, S.D., Santos, E.A., Pezzopane, J.E.M., Reis, E.F. (2010). Coffea canephora seedlings in the under shading and full sun. Engenh Agr. 18(3):219-226.

[88] Valladares, F., Sanches-Gomes, D., Zavala, M.A. (2006). Qua the gap between the evolutionary concept and its ecological quantitative estimation of phenotypic plasticity: birdging applications. J Ecol. 94:11031116.

[89] Vaast, P. Bertrand, B., Perriot, J. J., Guyot, B., and Génard, M.( 2006). Fruit thinning and shade improve bean characteristics and beverage quality of coffee (Coffea arabica L.) under optimal conditions. Journal of Science, Food and Agriculture 86: 197-204.

[90] Vaast, P., van Kanten, R., Siles, P., Dzib, B., Franck, N., Harmand, J.M., Ge'nard, M.( 2005a). Shade: a key factor for coffee sustainability and quality. Proceedings of the 20th International Congress on Coffee Research, Bangalore, India. ASIC, Paris, France, pp 887-896 
[91] Vaast, P., Angrand, J., Franck, N., Dauzat, J., Ge'nard, M. (2005c). Fruit load and branch ring-barking affect carbon allocation and photosynthesis of leaf and fruit of Coffea Arabica in field conditions. Tree Physiol 25:753-760

[92] Vaast, P., Salazar, M., Martinez, M., Boulay, A., Harmand, J.M., Navarro, G. (2007b). Importance of tree revenues and incentives of the programme "Coffee-Practices" of Star bucks for coffee farmers in Costa Rica and Guatemala. Proceedings of the 21st International Congress on Coffee Research, ASIC, Montpellier, pp. 495-502

[93] Van Oijen, M. J., Dauzat, J.M., Harmand, G.J., Lawson and Vaast, P. (2008). Plot-scale modelling of coffee agroforestry systems in Central America. Revista Agroforesteria en las Americas. Sub.

[94] Yacob Edjamo, Tesfaye Shimber, Taye Kufa, Anteneh Netsere, Takele Negewo and Alemseged Yilma. (1996). Advances in Coffee Agronomy Research in Ethiopia. Pp 40-55. In: J. S. Tenywa, Adipala Ekwamu and M. W. Ogengu-Latigo (eds.). Proceedings of Inter-Africa Coffee Organization (IACO) Workshop, 4-6 September 1995, Kampala, Uganda.

[95] Yunianto, Y.D. (1986). Overbearing dieback on Arabica coffee. J. Pel. Parkebu, 2(2):60-65.

[96] Wintgens, J. N. (ed.). (2004). Coffee: Growing, Processing, Sustainable Production. A guide for growers, traders and researchers. WILEY-VCH Verlag GmbH and Co.KGaA, Weinheim, Germany.

Citation: Abebe Assefa , Amisalu Gobena, "Review on Effect of Shade Tree on Microclimate, Growth and Physiology of Coffee Arabica: In case of Ethiopia", International Journal of Forestry and Horticulture (IJFH), vol. 5, no. 2, pp. 31-46, 2019. Available: DOI: http://dx.doi.org/10.20431/2454-9487.0503004

Copyright: (C) 2019 Authors. This is an open-access article distributed under the terms of the Creative Commons Attribution License, which permits unrestricted use, distribution, and reproduction in any medium, provided the original author and source are credited. 